Çeşm-i Cihan:

Tarih Kültür ve Sanat Araştırmaları E - Dergisi ISSN: 2149-5866 Cilt:8, Sayı:1, s. 92-113, Yaz 2021

Araștırma-İnceleme

DOİ: 10.30804/cesmicihan.874680 BARTIN - TÜRKIYE
Bartın Üniversitesi

Bartın ve Yöresi

Tarih - Kültür Araştırmaları

Uygulama ve Araştırma

Merkezi

(BAYTAM)

\title{
PEYAMİ SAFA'NIN HİKÂYECILIIĞİ VE KİTAPLARINA GİRMEMİŞ BİR HİKÂYESİ
}

\section{Sevde DUMAN*}

Öz: Üretken bir yazar olan Peyami Safa, yaşamı boyunca yüzü aşkın hikâye kaleme almıștır. İlk hikâyelerini Yirminci Asır gazetesinde, "Asrın Hikâyeleri" başlığı altında neşretmiştir. Halk arasında adının duyulmasını sağlayan bu ilk hikâyeleri günü gününe kaleme alınan, sanatsal kaygılarla ortaya çıkmayan metinlerdir. Hikâyelerinde, sıradan insanlara ve onların yaşamlarına objektifini çevirmiş, oradan elde ettiği malzemeyi kendi muhayyilesinde yoğurup halka sunmuştur. Daima sıradan insanları merkeze koymuş, toplumun hemen hemen her kademesindeki insanları hikâyelerine dâhil etmiştir. Peyami Safa üzerine yapılan çalışmalarda ağırlıklı olarak romanları üzerinde durulmuş, hikâyeleri çok fazla incelenmemiştir. Onu tam manasıyla anlamak için mutlaka tüm hikâyelerinin incelenmesi gerekmektedir. Çünkü bunlar, romanlarına giden yolda yazarın kalemini güçlendiren ve fikirlerini olgunlaştıran ilk örnekler olması bakımından önem arz etmektedir. Bu çalışmada Peyami Safa'nın hikâyeciliği ele alınacak, hikâyelerindeki konu, şahıs kadrosu, zaman, mekân, dil ve anlatım unsurlarına dair genel bir değerlendirme yapılacaktır. Ardından kitaplarına girmemiş olan "Oyuncak" adlı hikâyesinden bahsedilecek ve hikâyenin tam metni verilecektir.

Anahtar Kelimeler: Peyami Safa, Yirminci Asır, Hikâye, Türk Edebiyatı, "Oyuncak".

\section{PEYAMI SAFA'S STORYTELLING AND A STORY WHICH DID NOT TAKE PLACE IN HIS BOOKS}

\begin{abstract}
Peyami Safa, a prolific writer, wrote more than a hundred stories in his lifetime. He started to publish his first stories in the Yirminci Asır newspaper, under the title "Asrın Hikâyeleri". The first stories, which make his name heard among the public, are texts written day by day which do not arise with artistic concerns. In his stories, turned his objective into ordinary people and their lives, combined the material he obtained from there in his own imagination and presented it to people. It has always put ordinary people at the center and included people at almost every level of society in their stories. Studies on Peyami Safa mainly focused on his novels and his stories were not studied much. In order to fully understand him, all of his stories must be examined. Because these are important in that they are the first examples that strengthen the author's writings and mature his ideas on the way to his novels. In this study, Peyami Safa's storytelling will be discussed, a general assessment of the subject, people, time, space and elements of language and expression will be generally evalusted. Afterward, never mentioned the story of him called "Oyuncak" will be discussed and the full text of the story will be given.
\end{abstract}

Keywords: Peyami Safa, Yirminci Astr, Story, Turkish Literature, “Oyuncak”.

* Trakya Üniversitesi, Sosyal Bilimler Enstitüsü, Yeni Türk Edebiyatı Anabilim Dalı, Yüksek Lisans Öğrencisi, Edirne, ORCiD ID: 0000-0001-9474-6476 sevdeduman401@gmail.com 


\section{Giriş}

Cumhuriyet dönemi Türk edebiyatının en üretken yazarlarından biri olan Peyami Safa, roman, hikâye, makale ve fıkra gibi pek çok türde eser vermiştir. Edebiyat dünyasında ise romanları ve romancı kimliğiyle ön planda olan yazar, altmış iki yıllık yaşamı boyunca yüzü aşkın hikâye kaleme almıştır. Ancak bu hikâyelerin tamamını ayrıntılı ve kapsamlı biçimde inceleyen bir çalışma bulunmamaktadır. Nitekim onun üzerine yapılan çalışmalara bakıldığında romanlarına ağırlık verildiği, hikâyelerinin üzerinde fazlaca durulmadığı görülmektedir. "(...) Safa'nın romanları üzerinde inceleme yapmadan önce hikâyelerinin mutlaka okunması (...)" (Șen, 2008: 581) ve tetkik edilmesi lazımdır. Çünkü bunlar, romanlarına giden yolda yazarın kalemini güçlendiren ve fikirlerini olgunlaştıran ilk örnekler olması bakımından önem arz etmektedir.

Peyami Safa bir roman yazarı olarak tanınsa da edebiyat dünyasındaki ilk şöhretini romanlarına değil hikâyelerine borçludur. Yazar, ağabeyi İlhami Safa ile birlikte Yirminci Asır adlı bir gazete çıkarmaya başlar. Bu gazetede "Asrın Hikâyeleri" başlığı altında neşrettiği hikâyeleri halk tarafından büyük bir rağbet görür. Halkın ilgisi, edebiyatçıların teşvikleriyle cesaretlenen yazar, başlarda imzasız neşrettiği hikâyelerine imza atmaya başlar. Peyami Safa, bu durumu Cahit Sıtkı Tarancı'ya verdiği mülakatta şöyle anlatmaktadır:

On dokuz yaşımda kardeşimin teşvikiyle, muallimlik ve memuriyet hayatından matbuata geçerek "Yirminci Asır" adlı bir akşam gazetesi çıkarmaya başladık. Orada, "Asrın Hikâyeleri” başlığı altında, ilk otuz kırk tanesi imzasız ve tamamıyla halk için gazete hikâyeleri yazmaya başladım. Bu hikâyeler o zaman halk arasında beni hâlâ hayrete düşüren bir muvaffakiyet kazandı. 0 zamanın genç edebiyatı beni hararetle teşvik ediyor, hikâyelerime imza atmamı istiyordu. Yakup Kadri "Bize bir üslup getirdin." diyor, Yahya Kemal, sonra başkaları için çok tekrarlanan bir esprit ile "İsmail Safa'nın en güzel eseri Peyami'dir." diyordu. Ömer Seyfettin, Faruk Nafiz ve daha birçokları, bana gelen cesareti cömert ellerle dağıtanlar arasındadırlar. Sonra imza atmaya başladım. (Tarancı, 1940, 2-3)

Peyami Safa'nın “Asrın Hikâyeleri” başlığı altında neşrettiği hikâyeleri sanatsal kaygılarla ortaya çıkmayan metinlerdir. Yazarın hikâyelerinden bahsederken kullandığı ifadeler bu tespiti destekler niteliktedir: "Fakat hâlâ bu yazılar, beni, edebiyata girmiş olmak vakıasına inandıracak kuvvette şeyler olduklarını bizzat bana kabul ettirmekten çok uzak, günü gününe çırpıştırma karalamalardır" (Tarancl, 1940, 2-3). 
Peyami Safa, "Asrın Hikâyeleri" sayesinde kavuştuğu ünün ardından gözünü roman sahasına çevirir. "İlk romanı olan Sözde Kızlar'ı yirmi iki yaşında yazmış ve neşretmiştir" (Göze, 1987, 11). "Sözde Kızlar"ın ardından roman sahasında eser vermeye yoğunlaşsa da hikâye yazmayı bırakmaz. "Peyami Safa'nın 103 hikâyesi Halil Açıkgöz tarafından derlenerek 1980 yılında Ötüken Neşriyat tarafından Hikâyeler başlĭğ ile yayımlanmıştır” (Șen, 2008: 577). Ancak "Elinizdeki kitapta bütün hikâyeler bir araya getirilmiş değildir. Zaten, kitabın da hacminden anlaşılacağı üzere, hikâyelerinin tamamı bir kitabın çerçevesini aşacak derecede çoktur" (Safa, 2019, 18).

Yaptığımız araștırmalar sonucunda Peyami Safa'nın kendi adıyla yayımladığı "Oyuncak" adlı bir hikâyeye ulaştık. Bu çalışmada, Peyami Safa'nın hikâyeciliği ele alınacak, devamında kitaplarına girmemiş olan "Oyuncak" adlı hikâyesinden bahsedilecek ve hikâyenin tam metni verilecektir.

\section{Peyami Safa'nın Hikâyeciliğine Bir Bakış}

İyi bir gözlemci olan Peyami Safa, hikâyelerinde sıradan insanlara ve onların yaşamlarına objektifini çevirmiş, oradan elde ettiği malzemeyi kendi muhayyilesinde yoğurup halka sunmuştur. Merkeze koyduğu sıradan insanı zaaflarıyla, sorunlarıyla, yaşadığı zorluklarla ve en kötü yönleriyle ele almıştır. Bunu yaparken çoğu kez bireyin iç dünyasına, eylemlerinin asıl sebebine, ruhsal yapılarına yönelmemiştir. Ancak bireyin diğerlerinden ayrılan bir yönü ya da huyu varsa bunu da belirtmekten geri kalmamıștır.

Yazar, sıradan insanı merkeze koymakla kalmamış, aynı zamanda bunların yaşamları boyunca karşılaştıkları hemen hemen her olayı hikâyelerine konu edinmiştir. Kimi zaman cinsel arzularla hareket eden gençlerin kısa aşk maceralarını anlatırken kimi zaman da âşık olduğu kadının gerçek yüzünü öğrenen erkeklerin intihara sürüklenme süreçlerini anlatmıştır. Bazen hayat kadınlarının yaşamına odaklanmış bazen de yönünü bir doktor ve hastasına çevirmiştir. Genellikle farklı statüdeki insanların farklı yaşamlarını anlatmaya özen göstermiştir. Böylelikle hikâyelerindeki konuların geniş bir alana yayılmasına da zemin hazırlamıștır. Onun hikâyelerindeki konu dağılımıyla ilgili, edebiyat dünyasının önemli akademisyenlerinden Orhan Okay (2002: 435) şunları söylemiştir:

$\mathrm{Bu}$ hikâyelerden hemen tamamı magazin dergilerinde ve benzeri gazete sayfalarında yayımlanmış ve bu gibi yayınların okuyucusuna hitap edecek seviyede hafif konular üzerine kurulmuştur. Çoğu İstanbul'un çeşitli semtlerinde geçen olaylarda 
kadın-erkek ilişkileri, basit aşk, kıskançlık ve çapkınlık vakaları, arada dolandırıcılık, sahtekârlık, hırsızlık gibi biraz da zekâ oyunları tekrarlanır.

Safa'nın hikâyelerinde zengin bir şahıs kadrosu dikkat çekmektedir. Toplumun hemen hemen her kademesindeki insanlar, hikâyelerde az ya da çok kendilerine yer bulurlar. İşte bu insanları ekonomik durumlarına, mesleklerine, cinsiyet ve yaşlarına, medeni hâllerine ve eğitimlerine göre şöyle sinıflandırmak mümkündür: ${ }^{1}$

\section{EKONOMIK DURUMLARINA GÖRE İNSANLAR}

1. Zenginler: Rahmi ("Elli Yaşında Bir Adam": 420-425), Şivekâr ("Kırkından Sonra": 201-203), Hasan Bey ("Hasan Bey'le Rekabet": 180-186), Emine Teyze ("Emine Teyze": 147-150), Nazime Hanım ("Çürük Diş": 274-276), Cemil-Semahat ("Olağan Şeyler": 226-228), Sabri Bey (“Çuruk": 91-99), Usta Todori (“Sarı Lekeler": 45-48).

2. Fakirler: Saime ("Birçokları Gibi”: 53-56), kadın (“Nafile Gayret”: 157-161), Küçük Ali ("Bayram Hediyesi": 162-165), Mahmut-Şaziye ("Emine Teyze": 147-150), Âdil Efendi (“İlk Așk”: 286-289), adam ("Sokakta Kalan Şair”: 434-439).

\section{MEDENİ HÂLLERİNE GÖRE İNSANLAR}

1. Evliler: Seniha-Şinasi ("İçkinin Fazileti”: 216-219), Cemil-Semahat ("Olağan Şeyler": 226-228), Selma-Cevat ("Selma'nın Üzüntüsü": 190-192), Melike-Haluk (“Unutulmayan Bir Hatıra”: 196-198 ), Halit-Cemile (“Kazara mı?”: 206-207), HulusiKadın (“Bazı Kere Hayvanlaşırız": 57-60).

2. Dullar: Şaban Efendi ("Bir Cuma Gecesi”: 223-225), Vasıf Bey (“Gayet Müşkül Bir Vaziyet":235-237 ), Mükerrem ("Boşandıktan Sonra": 208-211), Sabahat ("Çay Daveti”: 142-146), Melahat Hanım ("Elli Yaşında Bir Adam": 420-425), Melek ("Pembe Yalı Efsanesi": 340-344).

3. Bekârlar: Muazzez ("Hangisi?": 219-220), Jülide ("Mezad Malı": 238-240), Fahri (“Aşksızlar”: 236-239), Hasan Bey (“Hasan Bey’le Rekabet”: 180-186).

\section{CINSIYYET VE YAŞLARINA GÖRE İNSANLAR}

1. Genç Kızlar: Jülide ("Mezad Malı": 238-240), Semahat ("Olağan Şeyler": 226-228), Pasaklı Gülsüm-Naime ("Pasaklı Gülsüm”: 109-113), Makbule-Perihan (“Çuruk": 9199), Zerrin (Kör Așk: 65-69), Karmen (“Çingeneler Cazibelidirler": 37-40), Nevin ("Lastik Top": 41-44), Fahriye-Behire-Makbule ("Sarı Lekeler": 45-48), Sezâ

1 Sınıflandırma yapılırken Halil Açıkgöz tarafından hazırlanan Peyami Safa-Hikâyeler adlı eser esas alınmıştır ve çalışmada geçen sayfa numaraları bu esere aittir. Ayrıca eserdeki tüm hikâyeler incelense de hepsi teker teker sınıflandırılmaya alınmamış, tipik birkaç örnek verilmeye çalıșılmıștır. 
(“Sezâcık”: 264-269), Zerrin (“ỉlk Aşk": 187-189), Mahmûre ("Kısa Günün Kârı”: 199200).

2. Delikanlılar: Hüsnü ("Mezad Malı": 238-240), Cemil ("Olağan Şeyler": 226-228), Mirza Ali ("Mirza'nın Așkı": 74-77 ), Raif (“Çingeneler Cazibelidirler”: 37-40), Âdil Efendi (“ilk Așk": 286-289), Fahri ve arkadașları ("Așksızlar”: 236-239), Hüseyin (“Muazzez Hanım'ın Aşkı": 264-267).

3. Çocuklar: Küçük Ali (“Bayram Hediyesi”: 162-165), Macit-Güzin (“illk Rüya”: 241242), Hüseyin (“Anadolu'da Bir Gece”: 345-350), Macit (“Gazi”: 359-363).

4. Orta yaşlılar ve yaşlılar: Rahmi ("Elli Yaşında Bir Adam”: 420-425), Fahri ("Gümüş Saplı Bir Baston": 426-427), Sabri Bey ("Çuruk": 91-99), Şemsettin Efendi ("Şemsettin Efendi'nin İzdivacı": 282-285), Şaban Efendi ("Bir Cuma Gecesi”: 223-225), Hayati Bey-Hâdiye Hanım ("Maaş Cüzdanı": 257-260), Hâdiye Hanım ("Hangisi?”: 219-220), Şivekâr Hanım ("Kırkından Sonra": 201-203), Emine Teyze (“Emine Teyze": 147150), kayınpeder (“İçkinin Fazileti”: 216-218).

\section{MESLEK GRUPLARINA GÖRE İNSANLAR}

1. Memurlar: Şemsettin Efendi ("Şemsettin Efendi'nin İzdivacı": 282-285), adam ("Tılsımlı Bir Kadın": 123-141), Bedri-Namık-Kamil ("Kıskanç": 78-81), Haydar Efendi-Hasan Efendi-Hamdi Bey ("Terakkiye Hazırlık": 376-382), Hamdi (“Erguvanlar": 331-335).

2. Avukatlar: Fazıl ("Karanlı̆̆ın Bir Şakası”: 204-205), adam ("Tılsımlı Bir Kadın”: 123141).

3. Doktorlar: Fuat ("Nafile Gayret": 157-161), Ahmet Faik ("Riza-yı Tarafeyn": 254256), Seyfi ("Dört Koca": 82-90), Fazll ("Pembe Yalı Efsanesi": 340-344), adam (“Tedavi”: 302-306), adam (“Ölen Sevgili": 311-314), adam (“Bir... Deli!”: 315-320).

4. Öğretmen: Kerim (“Dört Koca”: 82-90).

5. Hizmetçiler: Eleni ("Bazı Kere Hayvanlaşırız": 57-60), Hafize Hanım ("Pasaklı Gülsüm”: 109-113), Eleni ("Olağan Şeyler”: 226-228), Gülşen ("Erguvanlar”: 331335).

6. İtfaiyeciler: Hüseyin-Ali (“Bir Çift Küpe”: 248-250).

7. Dolandırıcılar/Hırsızlar: Ahmet Hamdi ("Doğru Hikâye": 410-419), adam ("Evhamlı Bir Yolcu": 229-231), adam ("Romatizmalı Bir Kol”:221-222), adam ("Bir Taşla İki Kuş": 246-247), Cin Hüseyin-Ali (“Yankesici”: 371-375). 
8. Yazarlar: Peyami Safa-Hasan Bey ("Nasll Tecennün Ettiler?": 212-215), adam (“Sokakta Kalan Şair”: 434-439), adam (“Bana Benzeyen Ölü”: 428-431).

9. Askerler: Kamil (“Unutmadın Değil Mi?”: 61-64), kumandan ("Hınç”: 151-156), Ahmet Halim ("Gece Saat Dokuzdan Ona Kadar": 70-73), Kadri ("Çllgın Bir Geceden Sonra": 104-108), adam ("Kara Bulut”: 243-245), adam ("Pasaklı Gülsüm”: 109-113).

10. Polisler: Necati (“Roza": 397-399), adam ("Bayram Hediyesi”: 162-165), adam ("Bir Taşla İki Kuş": 246-247).

11. Hayat Kadınları: Roza ("Roza": 397-399), kadın ("Çılgın Bir Geceden Sonra": 104108), kadın ("Karın Ağrısı": 114-119), Saime ("Birçokları Gibi”: 53-56), kadın ("Nafile Gayret”: 157-161), Zehra (“Gece Saat Dokuzdan Ona Kadar": 70-73).

12. Tüccar: Adam ("Vazife”: 405-406).

13. Falcı: Adam (“Falcı": 232-234).

14. Kuyumcu: Astik Efendi (“Bir Çift Küpe”: 248-250).

\section{EĞITIM DURUMLARINA GÖRE İNSANLAR}

1. Eğitimliler: Memduh-Cevdet-Sami ("Mavi Boncuk": 270-273), Rıfkı (“Unutmadın Değil Mi?": 61-64), Fazll ("Pembe Yalı Efsanesi”: 340-344).

2. Eğitimsizler: Pasaklı Gülsüm ("Pasaklı Gülsüm”: 109-113), Saime ("Birçokları Gibi”: 53-56).

Yukarıdaki sınıflandırmaya bakıldığında kadın kahramanların bazılarının eğitimsiz ve hayat kadını oldukları görülmektedir. Hayat kadını olanların bir kısmı yoksulluk sebebiyle bu mesleği yapmak zorunda kalmışlardır. "Birçokları Gibi”deki Saime, dayısı savaşta öldükten sonra anne ve babasını geçindirmek amacıyla fuhuş yapılan bir evde çalışmaya başlar. Para getirirse her şeyin değişeceğine inansa da durumlar hiç beklemediği bir yöne doğru evrilir. Babası, kızının kirli bir hayat yaşadığını öğrendikten sonra vefat eder. Annesi ise kızının kirli yollardan kazandığı kirli parasına tenezzül etmez ve bir yerde aşçılık yapmaya başlar. Anne ve babasını yoksulluktan kurtarmak için hayat kadını olan Saime, birkaç yıl sonra mesleği bırakmak, eski namuslu günlerine tekrar dönmek ister:

Birkaç defa bu evden kaçmak, bu hayatı terk etmek, namuslu ve sessiz hayatıma dönmek istedim. Fakat kabil mi?.. Bu hayat insanı bir yengeç gibi... yakalıyor ve asla bırakmıyor. Buraya istediğin zaman gelebiliyorsun, fakat istediğin zaman çıkamıyorsun. Çünkü seni buraya getirenler her şeyini düşünüyorlar. Omuzlarına ipek çarşaf, 
ayaklarına rugan iskarpin geçirdikleri zaman deftere senin hesabına iki yüz lira borç yazmayı da unutmuyorlar. Evet borcun var, bir yere gidebilir misin? (Safa, 2019, 53).

Yoksulluk sebebiyle ahlaksız bir hayat yaşamak zorunda kalan Saime ve türevlerinin hemen ardından ahlakî çöküntü yaşayan, namus gibi bir değere sahip olmayan evli kadınlar gelir. Bunlar, arzularının peşinden koşmayı tercih eden, kocalarının en yakınlarıyla yasak aşk yaşayan kimselerdir. Evli kadınların ihanetini anlatan hikâyelerden birkaçı şunlardır: "Sadık Bey'in Zevcesi”, “Tılsımlı Bir Kadın”, “Gümüş Saplı Baston”, "Bir İhanet Hikâyesi Daha”, "Mavi Gözlü Misafir”, "Hüseyin Bey'in Köpeği”, “Tehdit Mektubu”.

Hikâyelerdeki erkek kahramanlar incelendiğinde pek çoğunun eğitimli, çalışan, geçim derdi çekmeyen insanlar oldukları görülmektedir. Kadın kahramanların tam aksine erkekler, meslekleriyle ön plandadırlar. Avukat, doktor, öğretmen, asker, polis, yazar, kuyumcu gibi çeşitli meslek gruplarına dâhil olanlar daima erkeklerdir.

Bazı erkekler, hayat kadınlarını görür görmez âşık olurlar. Ancak ilerleyen zamanlarda âşı olduğu kadının ahlaksız yaşantısını öğrenen erkekler bu acı gerçeği kaldıramazlar ve intihar ederler. "Çılgın Bir Geceden Sonra" adlı hikâye bu tespitin en güzel örneklerinden biridir. Hikâyenin esas kahramanı Kadri Bey, genç, yakışıklı, her zaman temiz ve sade giyinen biridir. Nazik bir kadının romanlarda olduğu gibi kendisine âşık olmasını istemektedir. Kadri Bey bir gün yolda yürürken yanından geçen bir kadının kendisine seslendiğini fark eder ve hiç düşünmeden kadının arabasına biner. Bindiği arabanın sahibiyle sabaha kadar vakit geçirir. 0 kadını tekrar görmek isteyen genç zabit kadına bir türlü ulaşamaz. Hatta bir gün, kadının Göztepe'deki evine gider ancak hizmetliler tarafından dövülerek geri gönderilir. Kadri Bey, günlerce ulaşmaya çalıştı̆̆ı kadının gerçek yüzünü -hayat kadını olduğunu- öğrendikten sonra intihar eder. "Mirza'nın Aşkı"nda da buna benzer bir konu işlenmiştir. Mirza, bindiği vagonda yeşil gözlü, güzel ve alımlı bir kadınla karşılaşır ve onu elde etmek için dayanılmaz bir istek duyar. Kadının indiği durakta iner ve takibe başlar. Takip edildiğini anlayan kadın polis çağıracağını söyleyerek genç adamı yanından uzaklaştırır. Mirza, ilk defa gördüğü bu kadını günlerce, haftalarca düşünür. Seyahatin kendisine iyi geleceğini düşünür ve memleketi Tahran'a gider. Ancak bu yeni mekânda da zihni hep aynı şeyle -o kadınla- meşguldür. Mirza, tek çıkış yolunun âşık olduğu kadını bulmak olduğunu düşünür ve Tahran'daki tüm mal varlığını satıp İstanbul'a gelir. İstanbul'da haftalarca, aylarca o kadını arar.

Kadını aramaya başladı. 
Beyoğlu'nun içeri hayatını bilirmiş gibi, büyük bir laubalilikle her yere girip çıktı. Birçok avuçları kâğıt para ile okşadı, aradı arattırdı, sordu, soruşturdu. Bir arı kadar hararetle koşuyor, dolaşıyor, birçok akşamlar bitkin bir hâlde yatağa düşüyordu. Fakat nâfile... Nâfile, yok, yok, yok.

Böyle üç ay geçti (Safa, 2019, 76).

Mirza, aylarca aradığı kadınla tesadüfen Taksim Bahçesi'nde karşılaşır ve başından geçen macerayı olduğu gibi anlatır. Kadın ise bir metres olduğunu ve günde otuz lira kazandığını söyler. Mirza sevdiği kadının metres olduğunu öğrenince çok üzülür, evine gider, bir bıçak alır ve göğsüne saplayıp intihar eder. Hikâyede bu olay şöyle anlatılır:

Doğru apartmanına koștu, yatak odasına girdi, kapıyı kilitledi.

Bavulundan bıçağını çıkardı, göğsünü çözdü. Tenini açtı. Sol eliyle bıçağın ucunu kalbinin üstüne dayadı. Sağ eliyle arkasından karyolanın demirini tuttu. Gözlerini kapadı, dişlerini gıcırdatarak sıktı ve bıçağını bastırdı.

Belediye doktoru ölüyü muayene ederken onun dişlerinin kâmilen kırıldığını görmüştü (Safa, 2019, 77).

Peyami Safa'nın hikâyelerinde olaylara dekor olan mekân İstanbul'dur. "Hikâyelerdeki vakalar, bir iki tanesi istisna tutulursa, daima İstanbul'da geçer (...)" (Safa, 2019, 15). “Sadece iki hikâyesinin mekânı İstanbul dışıdır: "Beyrut'un Leylâ'sı" (s. 79) Beyrut'ta ve "Anadolu'da Bir Gece" (s. 328) Ilgaz Dağları'nda geçer" (Şen, 2008: 580). Olaylar genel olarak İstanbul'un Beyoğlu semtinde geçer. "Çingeneler Cazibelidirler"de esas kahraman Raif, yeni bir kadınla tanışmak için Beyoğlu'na gider. Bu adam, yeni bir kadınla tanışmak için yaptığı gezintide genç bir çingene kızıyla karşılaşır, çok etkilenir. Karmen adını verdiği kıza para karşılığında bir gece geçirmeyi teklif eder. Onun yeni tanıştığı bir kadına karşı yaptı̆̆ı bu teklif, ahlakî çöküntüsünün ne boyutta olduğunun da ispatı niteliğindedir. Çapkın bir genç olan Raif, Karmen'e sadece cinsel duygularla yaklaşır:

Raif gezinti yaparken bir Çingene kızını çok beğenir ve onunla cinsel bir beraberlik hayal eder. Kızın bunu kabul etmemesi üzerine onunla "kaçmaya", bir anlamda onun bütün sorumluluklarını üzerine almaya, bir nevi evlenmeye razı olur. Cinsel arzunun Raif'i hiç de planlamadığı bir iş yapmaya, bir Çingene kızıyla birlikte yaşamaya itmesi manidardır (Harmancı, 2012, 86). 
"Çingeneler Cazibelidirler" hikâyesinde en dikkat çekici şeylerden biri, kahramanın yeni bir kadınla tanışmak için seçtiği mekânın Beyoğlu oluşudur. Beyoğlu, Peyami Safa'nın hikâyelerinde Batılılaşmanın ve ahlakî çöküntünün simge mekânlarından biridir:

Beyoğlu, Şişli, Nişantaşı, Osmanbey vd. Avrupa'nın dejenere eden tesiriyle içki ve sefahat yuvalarıdır: Harp vurguncuları, üçkağıtçılar, kendi millî ve mânevî değerlerinden kopmuş insanlar, çöken Osmanlı aristokrat ailelerin fertleri, düşük kadınlar hep buralarda yaşamaktadırlar (Safa, 2019, 15).

Yazarın hikâyelerinde en az önem verdiği unsur zamandır. Hikâyelerde olayların gerçekleştiği zamanla ilgili kesin bir tarih ibaresine rastlamak oldukça zordur. Kesin bir tarih ibaresi kullanmasa da saat, gün, ay ve mevsim gibi zamanı ortaya çıkaracak ibarelere yer vererek okuyucunun vaka zamanını bulmasına imkân sağlamaktadır: "O gün cuma idi. Raif aynanın karşısında her günkünden fazla durdu. Bir saat kadar saçları, bıyıkları ve çehresinin bazı kısımlarıla meşgul oldu" (Safa, 2019, 37).

Olayların çoğu dar bir zaman dilimi içerisinde birkaç saat ya da günde olup bitmektedir. Dar bir zaman diliminde yaşanan olaylar kronolojik bir sıra takip edilerek anlatılmıştır. Bu tarzda oluşturulmuş hikâyelere şunlar örnek gösterilebilir: "Bazı Kere Hayvanlaşırız...”, "Gece Saat Dokuzdan Ona Kadar”, “Karın Ağrısı”, “Emine Teyze”, “Nafile Gayret,” “Bayram Hediyesi”, “Sadık Bey'in Zevcesi”, “Karanlığın Bir Şakası”, “Kazara Mı?”, “Romatizmalı Kol”, “Falcı”, “Mezad Malı", “İlk Rüya”, “Kara Bulut”, “Bir Taşla İki Kuş”.

Peyami Safa, hikâyelerinde günlük konuşma diline yakın, sade, açık ve anlaşılır bir dil kullanmıştır. Argo ve küfürlü kelimelere çok fazla yer vermemiştir. Genellikle kısa ve kurallı cümleler kurmayı tercih etmiştir. Ancak hikâye kahramanlarının fiziksel özelliklerini ve tavırlarını tasvir ederken uzun ve devrik cümleler kurma yoluna gitmiştir. İște bu cümlelerde sıfat ve benzetmelerden çokça yararlanmıştır:

Hınzır, eti canlı karı, ne de güzel ud çalar, ne de tatlı şarkı söyler, böyle bir taraftan çalıp bir taraftan söylerken ne de baygın göz süzüşü, gerdan kırışı, omuz titretişi, iç çekişi vardır, biraz kemikleri irice, büyücek ama, elma topuklu ayaklarını yere değdirerek usul tempo tutarken kısa bacaklarının lop etleri nasıl da löpür löpür sallanır, boğazından bir iki kadeh rakıyı damla damla, yudum yudum içine kaydırınca lop yanakları nasıl da pembeleşir, gözleri nasıl da felfecir okur, dudakları nasıl da şapırdar, hif (Safa, 2019, 224). 


\section{Hikâye Külliyâtı Dergisinde Yayımlanan Bir Hikâye: “Oyuncak”}

Peyami Safa sağlığında hikâyelerinin bir kısmını kitaplaştırma imkânı bulmuştur. Kitaplarında bulunmayan, gazete ve dergi sayfalarında kalan hikâyeleri ise 1980 yılında Hikâyeler başlığı altında yayımlanır. Ancak bu eserde yazarın tüm hikâyeleri bulunmamaktadır. Bu çalışmada tam metni verilecek olan "Oyuncak" adlı hikâye de Peyami Safa'nın kitaplarına girmeyen, gazete ve dergi sayfalarında kalan hikâyelerinden sadece biridir.

“Oyuncak”, “Birinci Dünya Harbi'nin nihayete erdiği 1918 yılında 13 sayı olarak Kitabhâne-i Sûdî tarafindan neşredilen Hikâye Külliyâtı" (Aykol, 2018: 101) dergisinin 12. sayısında yer almaktadır. Aynı sayıda Refik Halit Karay'ın “Şüphe” adlı hikâyesi de bulunmaktadır.

Hikâyenin kahramanları Muhittin, Macide ve Kamil'dir. Muhittin, eşi Macide ile birlikte mutlu mesut bir evlilik hayatı geçirmektedir. İkilinin arasında senelerdir küçücük bir tartışma bile yaşanmamıştır. Macide, eşlik vazifesini eksiksiz yerine getiren ideal bir kadındır. Bu yüce kalpli, asil kadının gribe yakalanıp ölmesi Muhittin'i derinden sarsar. Muhittin bir gün Macide'nin elbiselerini yerlerine asarken pembe bir kâğıt bulur. Kâğıdı gözden geçirmeye başlayınca acı gerçekle karşı karşıya kalır. Çok sevdiği, herkesin namus timsali olarak gördügü karısının kendisini aldattığını öğrenir. Kâğıt Muhittin'in en yakın arkadaşı Kamil tarafından yazılmıştır. Böylece hem eşinin hem de dostunun ihanetini beklenmedik bir şekilde öğrenmiş olur. Muhittin bir an önce bu ilişkinin nasıl ve ne șekilde başladığını öğrenmek istemektedir. Kamil'in Giresun'da olduğunu bildiği için onun İstanbul'a dönmesini bekler. Günler sonra Muhittin'i heyecanlandıran bir gelişme yaşanır. Kamil bir köylü kızıyla evlenip İstanbul'a gelmiştir. Silahını alıp dışarıya fırlayan Muhittin, köprüde Kamil ile karşılaşır. Bu karşılaşmada Kamil, Macide'nin öldüğünü öğrenir. Ardından bu yasak aşkın nasıl başladığını ve ne zaman sonlandırdıklarını anlatır. Muhittin duydukları karşısında şaşkınlık yaşar. Konuşmanın ardından Kamil’e kin duymadığını söyler ve oradan ayrılır. Kısaca tanıttığımız "Oyuncak” adlı hikâyenin tam metni şöyledir2:

\section{“Oyuncak”}

Keder ve ıstırap nedir? Muhittin bunu Macide'nin ölümünden sonra anladı. Hayatın hiçbir acısı, çok sevdiği zavallı karısının bu ebedî̉ ayrılışı kadar onu sarsmamıştı.

2 Hikâyedeki kelime anlamları verilirken şu sözlüklerden yararlanılmıştır:

Bkz: Devellioğlu, Ferit. Osmanlıca-Türkçe Ansiklopedik Lûgat. Ankara: Aydın Kitabevi Yayınları, 2000.

Bkz: Nişanyan, Sevan. Nişanyan Sözlük Çağdaş Türkçenin Etimolojik Sözlüğü. İstanbul: Liber Plus Yayınları, 2018.

Bkz: Türkçe Sözlük. Ankara: TDK Yayınları, 2005.

3 Sonsuz 
Bir türlü inanamıyordu: Daha beş altı gün evvel, bahçe üstündeki yemek odasından, karşılıklı iskambil atarken, çılgın, şen kahkahalar fışkıran, o değil miydi? Nasıl, hangi esrarlı4 kuvvet, bu taze, sağlam ve kuvvetli vücudu bir haftaya varmadan böyle sapsarı bir mumya hâline soktu?

Muhittin her şeye razı idi: Kötürüm kalmaya, bütün evlerinin ve dükkânlarının yanmasına, ölünceye kadar aç ve sefil yaşamaya... Her şeye, her şeye, yalnız buna değil, bu melun' ${ }^{5}$, habis ${ }^{6}$, korkunç düşmana: Ölüme! Ah, hayır, asla...

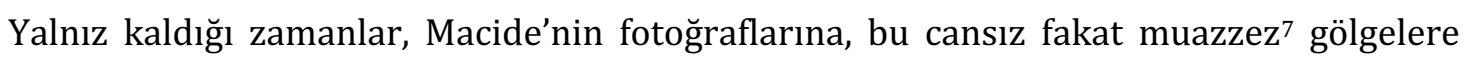
bakıyor, öyle saatlerce kalıyordu. Düşünüyordu ki hiçbir kadın Macide kadar asil ve yüksek bir kalbe mâlik ${ }^{8}$ olamazdı. İzdivaçlarından ${ }^{9}$ beri geçen asude $^{10}$ ve mesut seneleri hatırladı, aralarında küçücük bir mübahase ${ }^{11}$ şimşeği bile çakmamıştı. Onlar kimyevî iki zerrenin imtizacı12 $^{12}$ gibi birleşmiş, o kadar uygun yaşamışlardı. Hususiyle bu kadın zevcelik vazifesini ne kadar metin bir sadakatle ifa etmişti13. Etrafta herkes, bütün arkadaşları ve akrabası Macide’yi "namus" denilen eski asırların faziletini, bu yeni asırda büyük bir aşk ile taşıyan biricik kadınlar arasında görüyorlardı. Muhittin, yalnız tatlı ve taze bir vücuttan, iyi bir hayat arkadaşından değil, bir vazife ve fazilet havarisinden ${ }^{14}$ ayrıldığını da düşünüyordu.

Günlerce, haftalarca, aylarca zavallı Macide’nin hayali gözlerinin önünden ayrılmadı.

\section{料}

Bir gün kuvvetli bir iştiyak ${ }^{15}$, Muhittin'i Macide'nin, ölüm gününden beri girmediği odasına sürükledi.

Bu odada ölümün dağıtamadığı şuh ve mest edici bir hava vardı.

Muhittin, şuursuz bir hâlde, Macide'nin elbise dolaplarına koştu. 0 her biri ayrı bir hatıra taşıyan renk renk bluzları, sabahlıkları saatlerce öptü. Dantelalar, kurdele kıvrımları arasına

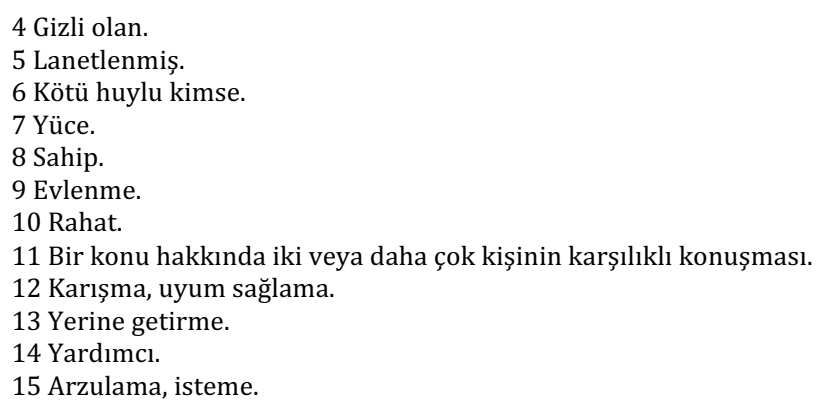


gizlenen ve ebedî kalmaya karar vermiş gibi görünen mahrem, hususi ve samimi rayihayl ${ }^{16}$, o vücutların değil, ruhların kokusuna benzeyen esrarlı rayihayı içti ve ağladı.

Bütün o ipek yığınları sıcak gözyaşlarıyla ıslandılar.

Muhittin, ince bir ihtimamla17, Macide'nin metruk ${ }^{18}$ elbiselerini yerlerine asarken "çıt" etti, yere pembe bir kâğıt düştü.

Bu bir kâğıt değil, kâğıtçıktı; üzerinde ince ince yazılmış altı yedi satır vardı. Altı yedi satır... Muhittin hemen bunları gözden geçirdi.

Ve bir saniye geçmeden, dolabın yanındaki koltuğa yığıldı. İlk defa olarak, Macide'nin kendisini aldattığını öğrenmişti.

Bu sefer kudurmuş coşkun bir hiddet damarlarını yaktı, sinirlerini kavurdu. Aldanmak! Bu kelime ruhunun içinde bir kestane fişeği gibi patladı. Demek ki aldanmıştı. Fakat nasıl? Hemen avcunun içine korkmuş gibi buruşarak sinen pembe kâğıdı açtı. İmzaya ve tarihine baktı. İmza=Kamil. Tarih Kânunuevvel ${ }^{19} 333^{20}$. Hayalinde bir vak'a çerçevesi teressüm²1 etti: 333 Kânunuevvelinde Muhittin iki ay kadar Peşte'ye ${ }^{22}$ gitmişti. İşte o zaman, Macide tereddüt etmeksizin kendisini Kamil'in, Muhittin'in o pek sıcak ve samimi arkadaşının kolları arasına atıor!

İşte o zaman... Fakat bunlardan hangisi daha kabahatli? Vak'a nasıl cereyan etmiş? Bunlar eskiden de görüşüyorlar mı imiş? Bir sürü müziçç sual ${ }^{24}$ zinciri, Muhittin'in beynine dolanarak sımsıkı bir demir dügüm halini aldı.

Vak’a nasıl cereyan etmiş? Yine pembe kâğıda müracaat. Orada Kamil diyor ki:

“Ey dünyanın en güzel kadını! Artık bu çılgın sergüzeştimize25 nihayet vermek lazım geliyor, bunu ben de senin kadar takdir ediyorum, çünkü Muhittin üç güne kadar İstanbul'da. Emin ol ki senin mukaddes ${ }^{26}$ ve ilahî bir kadın olduğuna nasıl emin isem, Muhittin'in de yüksek bir vicdan taşıdığına kanaatim var. Teklifini kabul ettim, bu kâğıdı yak.”

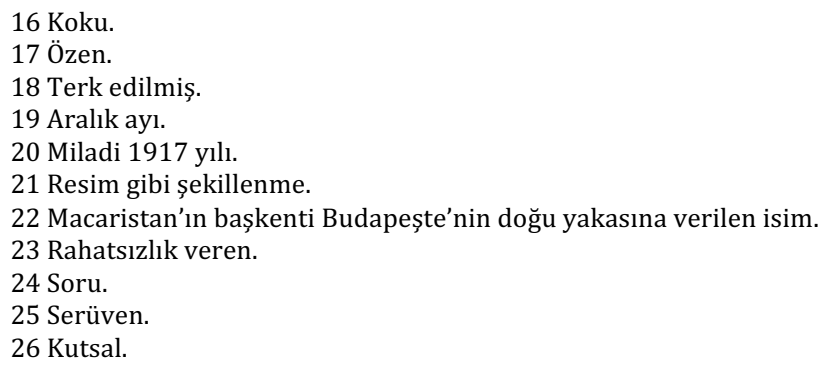


Pembe kâğıtta yalnız bu mühim satırlar vardı, başka hiçbir izah yok. Haftalar geçti. Muhittin'in ruhunu didikleyen bu korkunç muamma aydınlanmadı. Muhittin gece sabahlara kadar uykusunu parçalayan bu müthiş ve inatçı düğümü çözemedi. Kamil'i görmek iştiyakı onu kudurtuyordu. Fakat Kamil Giresun'da idi, onu görmek için beklemek lazımdı. Beklemek yani aylarca bu müziç kâbusun azapları içinde kıvranmak...

Fakat bir gün ona haber verdiler: Kamil gelmiş, İstanbul'da imiş, Kadıköy'de bir ev tutmuş. Haber veren bir zabit27 idi, gülerek ilave etti:

- Daha tuhafı nedir biliyor musun? Gelirken bir köylü kızıyla evlenmiş, onu da beraber getirmiş!

Muhittin, bir saniye beklemeden odasına koştu, revolverini28 aldı ve sokağa fırladı.

On dakika sonra köprüde idi, iskele merdivenlerini inerken karşısına kalpaklı ve görklü bir adam çıktı, ilk bakışta tanıyamadı, fakat o: "Muhittinciğim..." diye bağırıyordu: Kamil... Kamil, o kendisine şüphesiz dünyanın en yakıcı azaplarını çektiren adam. Muhittin mermer gibi durdu ve sert bir sesle:

- Ben de seni arıyordum.

Dedi.

- Mersi.

- Hem de bir buçuk aydan beri.

Kamil anlamadı:

- Bir buçuk aydan beri mi?

- Evet, Macide'nin ölümünden itibaren...

Kamil birdenbire sendeledi, parmaklığı tutmasaydı merdivenden arka üstü yuvarlanıyordu, hayretinden bir havuz gibi şişen gözlerini Muhittin'in gözlerine dikerek bağırdı:

- Macide öldü mü?

- Haberin yok muydu?

Kamil titriyordu. 
- Hayır, katiyen. Zaten son aylarda İstanbul'dan hiç mektup alamamıştım. Burada da duymadım, ev aramak belasından...

İkisi de susuyordu. Atlar gibi merdivenleri indiler. Kamil boğazına sıkışan bir hıçkırık düğümünden kurtulmak istedi:

- Neden, hastalı̆̆ı?

- Grip.

- İstanbul gribi?

Sözünü bitiremedi, gözlerindeki yaşlar, Kamil'in o kadar nefsini zorlamasına rağmen yanaklarında yuvarlandı. Ağlıyor! Bu manzara Muhittin'e çok tuhaf göründü. Ağlıyor, ne için?

Sordu:

- Ne için ağlıyorsun?

Kamil yarı itiraf etti:

- Hiçbir haber beni bu kadar müteessir29 edemez. Ben Macide'yi evvela senin zevcen olduğu için, sonra da... Bilmem ne için fazlaca severdim.

Muhittin'in derhal erkeklik damarı tuttu, kan beynine sıçradı, Kamil'i kolundan tutarak, sürüklercesine deniz üstündeki parmaklı̆̆ın tenha bir köşesine çekti, dişlerini sıkarak mirıldandı:

- Demek itiraf ediyorsun?

- Neyi?

- Alçaklığını...

Birbirlerine bakıştılar. İkisinin de ruhunda fırtına vardı. Kamil, boğazına kadar çıkan hıçkırıkları boğmaya çalışarak, sakin bir sesle söyledi:

- Artık muazzez bir ölünün arkasındayız. Gizlemeye ne lüzum var? İşte kısaca, bütün olan biteni sana anlatıyorum: Sen Peşte’ye gittiğin zaman sizin evin yarım kalan işlerini yapmak için haftada iki kere evinize uğruyordum. Bu salahiyeti30 bana bizzat sen verdiğin için bunda tereddüt etmedim. Her gidişimde Macide beni kapının yanındaki misafir odasına alıyor, bana bir kahve yahut bir kadeh likör31 ikram ediyordu. Bunu tabiî gör, çünkü komilfo ${ }^{32}$ bir kadından 
başka türlü hareket beklenmezdi değil mi... Ve sana yemin ederim, bu böyle, sen gelinceye kadar devam edecekti. Fakat bak, onu da, beni de çığırımızdan çıkaran ne oldu. 0 ki elbette dünyanın en namuslu, vazifesini bilir kadını idi. Dinle, bir sabah, fakat bilir misin nasıl bir sabah? Taze, kokulu ve çıldırtıcı bir ilkbahar sabahı. Ilık bir hava burundan girerek, bütün ciğerleri ve kanı dolaşarak orada kıvılcımlar tutuşturuyor. Her şey neşe içinde: Yollardaki ağaçlar, yeşil otlar, hayvanlar, hatta taşlar bile ve insanlar, insanlar ve kadınlar... Bir ilkbahar sabahı ki kışın karanlık ve vahşi günlerinden kurtulan bütün varlıkları coşturuyor, çlgın zapt olunmaz bir meserrete $33^{33}$ boğuyor. Ben, bütün kendime mahsus acl felsefelerime rağmen, sebepsiz bir sevinçle evden çıktım, defterime baktığım zaman sizin eve uğramak mecburiyetinde olduğumu anladım, tramvaya atlayarak geldim. Zevcen zavallı Macide, o da tabiatın bu delişmen gününden çok kaynamış olacak, beni taşkın bir meserretle karşıladı. Bana bir yerine üç likör verdi, mutat ${ }^{34}$ haricinde kendisi de içti. Hemen havanın sarhoş edici güzelliğinden bahsettik, o, çiçeklerinin o gün her gününden daha güler yüzlü olduklarını anlattı ve görmek isteyip istemediğimi sordu. Memnun, kabul ettim, bahçeye çıktık. Bilmem sen mi yaptırmışsın, bahçede bir salıncak var...

Muhittin kesti:

- Yeter, anlatma, daha fazla dinleyemem, yalnız bir sual: Ondan sonra kaç defa görüştünüz.

Kamil biraz düşündü, sonra kekeledi:

- Her gün, sen gelmeden üç gün evveline kadar. Üç gün evvel, birlikte düşündük, taşındık, sana karşı yaptığımız hakarete nihayet vermek istedik. Ben de bildiğin gibi, hemen Giresun Umuru Hukukiye Müdürlüğü’nü kabul ettim ve İstanbul’u terk ettim. O ise... Zavallı.

Kamil'in yüzü tekrar buruştu. Kıpkırmızı olan gözleri bu sefer fasılasız yaşlar dökmeye başladı. Hıçkırıkları arasında:

- Beni öldür. Bu senin hakkındır.

Dedi.

Muhittin... 0 da titriyordu. Asabi parmaklarıla ceketinin düğmelerini büküyor, koparıyordu. Birdenbire sordu:

- Kamil doğru söyle onu sevdin mi? 
- Evet, çıldırasıya. Hem hâlâ. O bunu bilmez, söylesem de inanamazdı. Zaten söyleyemezdim, çünkü sana pek şiddetli bir merbutiyeti vardı.

Muhittin'in ruhunda bir boğuşma oldu. Kendisini Kamil'in yerine koydu, o bütün insanı delirten baharı ve bütün insanların vücudunda gizlenen hayvanî makineyi düşündü. Bunlar mücrimdiler35, şüphesiz... Affetmeli miydi?

Birdenbire elini arkadaşının omuzuna vurdu:

- Kamil... Artık bundan bahsetmeyelim, sana karşı küçücük bir kinim bile yok.

Dedi ve hemen ayrlld.

Köprünün üzerinde sağa sola koşuşan, kan içinde kalan, kimi bir servetin, kimi bir kadının, kimi bir lokma ekmeğin arkasında yuvarlanan insan yığınlarına baktığı zaman:

- Bunlar ölecek... diye mırıldandı, madem kör talihin birer oyuncă̆ıyız?” (Safa, 1918, 811).

\section{Sonuç}

Peyami Safa, sıradan insanların yaşamları boyunca karşılaşabilecekleri hemen hemen her olayı ve sorunu hikâyelerinin ana malzemesi hâline getirmiştir. Kimi zaman sıradan bir insanın ailesini geçindirmek için sabah akşam iş bulma gayretini anlatırken kimi zaman da cinsel arzularla hareket eden iki âşığın yaşadıklarını anlatmıştır. Bir hikâyesinde hayat kadınlarının yaşamına odaklanırken bir başka hikâyesinde bir doktora ve onun hastasına odaklanır. İşte onun bu tavrı hikâyelerinde geniş bir konu yelpazesinin ortaya çıkmasına sebep olmuştur.

Hikâyelerinde geniş bir şahıs kadrosu vardır. Bu kadrodaki kadın kahramanların bir kısmı yoksulluk ya da savaş yüzünden kötü yola düşmüş kimselerken bir kısmı da evli olmalarına rağmen arzularının peşinde koşmayı tercih edip eşlerini aldatan, ahlak ve namus gibi değerlere sahip olmayan evli kadınlardır. Bu kadınların tam zıddı kadınlarla da karşılaşmak mümkündür. Ancak bunların daima azınlıkta olduğu görülmektedir.

Erkek kahramanların pek çoğu geçimini idame ettirmek için bir başkasına muhtaç olmayan, maddi açıdan pek de sıkıntı çekmeyen eğitimli, meslek sahibi kimselerdir. Avukat, polis, doktor gibi meslek gruplarına mensup olanlar daima erkeklerdir. 
Halkın yaşamını hikâyelerine konu olarak seçen yazar, dil ve üslupta da halktan yararlanmış, halkın anlayabileceği sade, açık ve anlaşılır bir dil kullanmıştır. Daha çok kısa ve kurallı cümleler kurmuştur.

Peyami Safa'nın hikâyelerinin bir kısmı kitaplarına girmemiş, gazete ve dergi sayfalarında kalmıştır. Bu çalışmada tam metni verilen "Oyuncak", kitaplarına girmeyen hikâyelerinden sadece biridir. "Oyuncak", Hikâye Külliyâtı dergisinin 12. sayısında yayımlanan, yasak aşk ve ihanet konularına odaklanan kısa bir hikâyedir. Hikâyede eşinin ihanetini beklenmedik bir şekilde öğrenen bir adamın ihaneti öğrenme aşaması ve sonrasında yaşadıkları ayrıntıya girilmeden, en genel hatlarıyla anlatılmıştır.

\section{KAYNAKÇA}

Aykol, Ufuk. “Kitabhâne-i Sûdî’nin Hikâye Külliyâtı”. Türk Dili, 115/801 (Eylül 2018): 101-106.

Devellioğlu, Ferit. Osmanlıca-Türkçe Ansiklopedik Lûgat. Ankara: Aydın Kitabevi Yayınları, 2000.

Göze, Ergun. Peyami Safa. İstanbul: Kültür ve Turizm Bakanlığı Yayınları, 1987.

Harmancı, Abdullah. "Peyami Safa Öykücülüğüne Tematik Bir Yaklaşım”. Erdem, 62 (2012): 83-98.

Nişanyan, Sevan. Nişanyan Sözlük Çăgdaş Türkçenin Etimolojik Sözlüğü. İstanbul: Liber Plus Yayınları, 2018.

Okay, Orhan. "Peyami Safa” Maddesi. Büyük Türk Klasikleri. 13: 435. İstanbul: Ötüken-Söğüt, 2002.

Safa, Peyami. Oyuncak. Hikâye Külliyatı. İstanbul: Matbaa-i Orhaniye, 12 (1918): 811.

Safa, Peyami. Hikâyeler. İstanbul: Ötüken Neşriyat, 2019.

Şen, Can. 'Peyami Safa'nın Hikâyeciliği Üzerine Bir İnceleme”. Türk Dili, 684 (Aralık 2008): 574-581.

Taranc1, Cahit S1tkı. Peyami Safa: Hayatı ve Eserleri. İstanbul: Semih Lütfi Kitabevi, 1940 .

Türkçe Sözlük. Ankara: TDK Yayınları, 2005. 


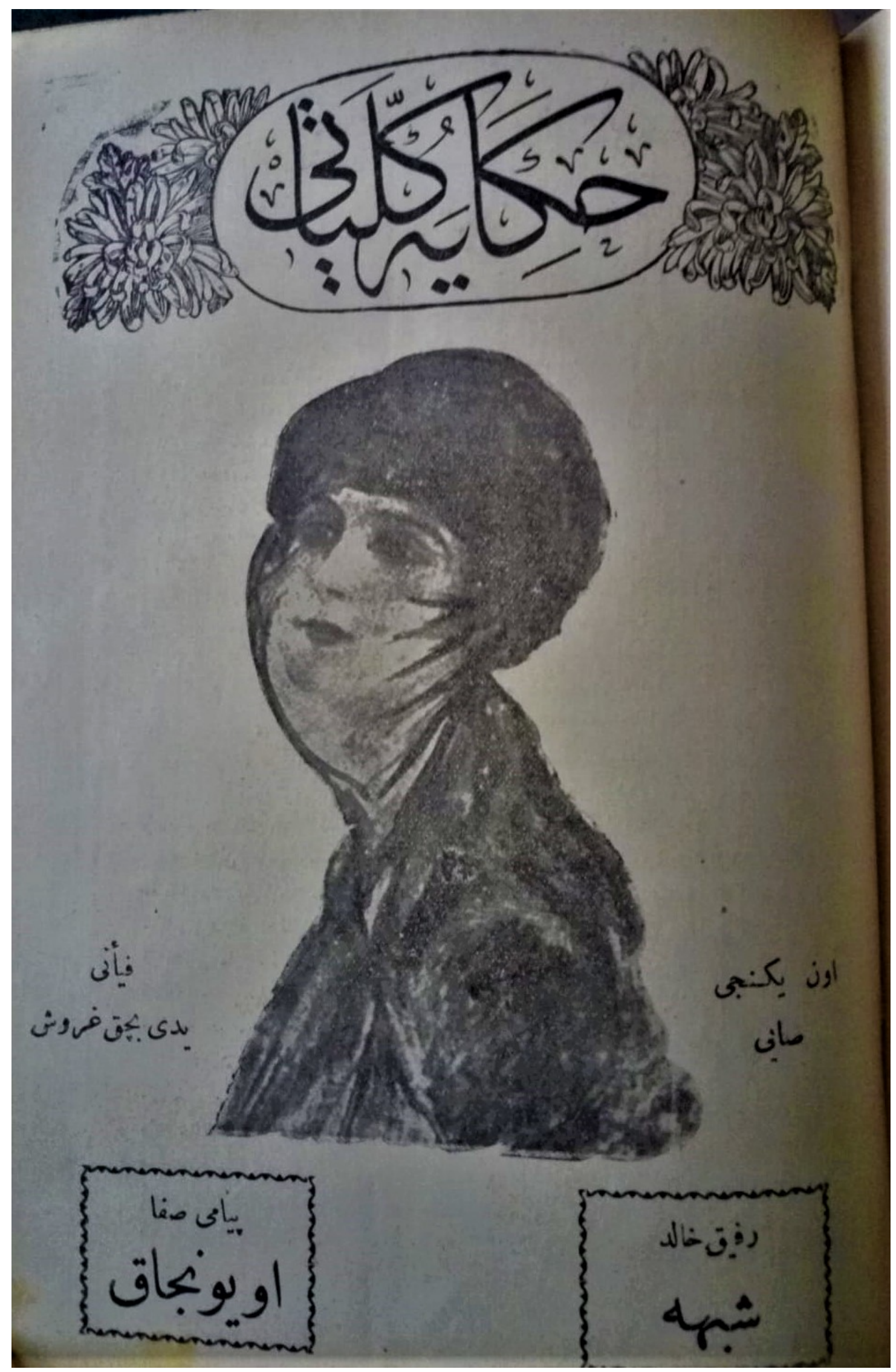




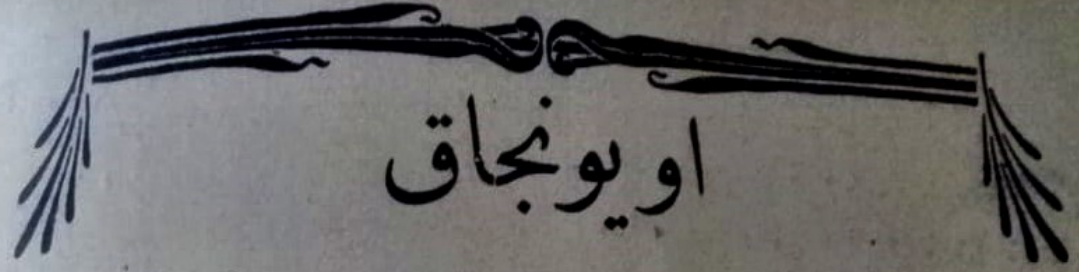

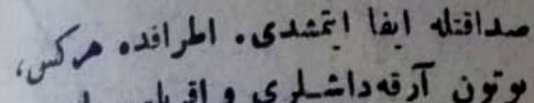

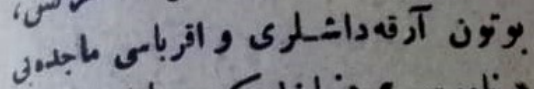

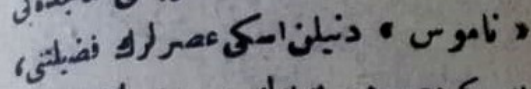

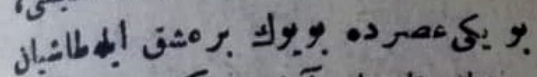

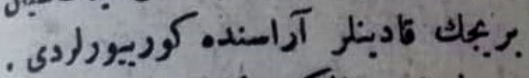

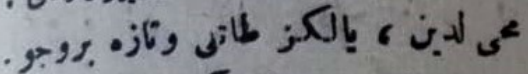

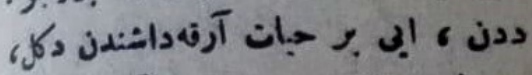

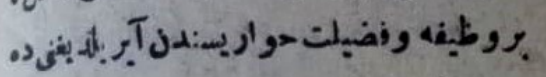

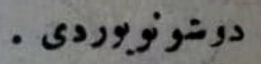

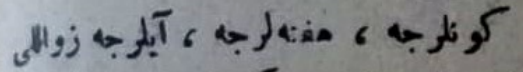

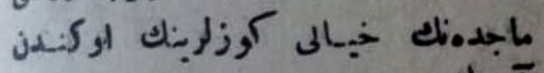

$$
\text { ** }
$$$$
\text { - }
$$

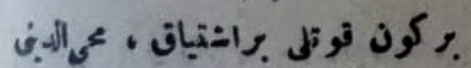

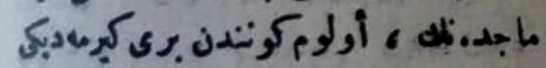

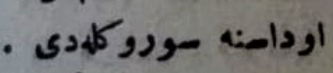

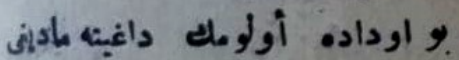

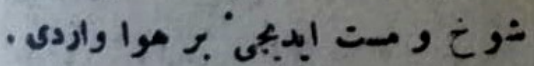

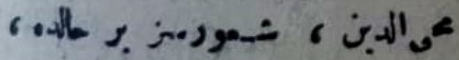

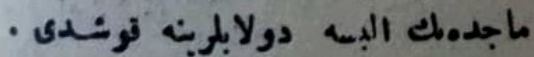

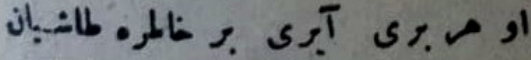

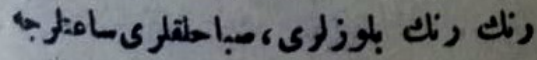

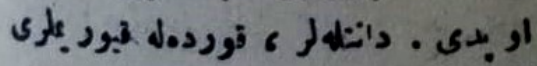

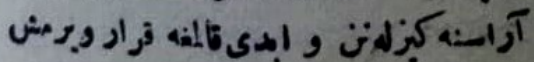

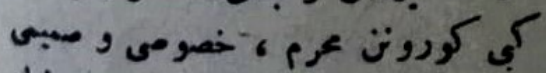

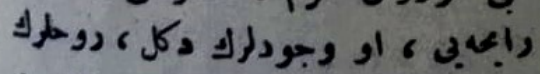

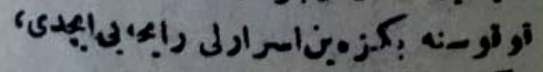
وتود او ابـاك بين:لادى صبهان. ef

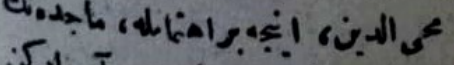

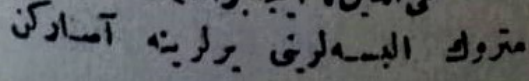

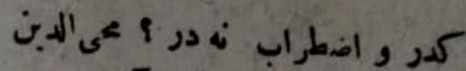

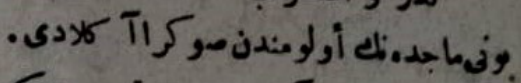

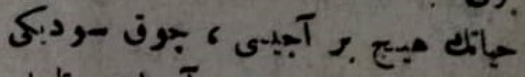

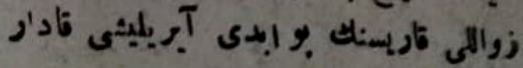

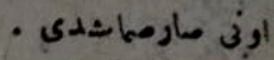

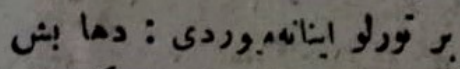

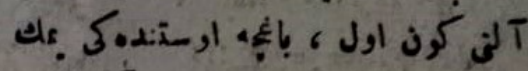

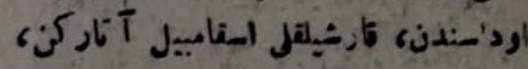

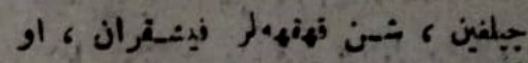

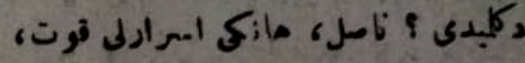

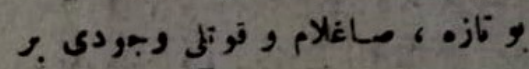

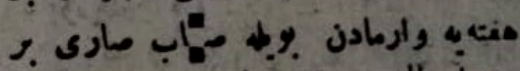

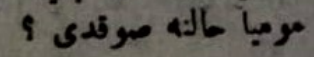

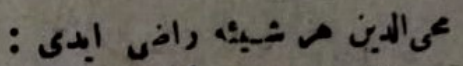

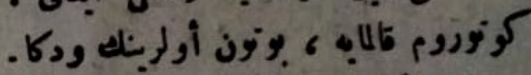

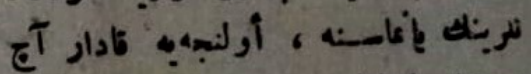

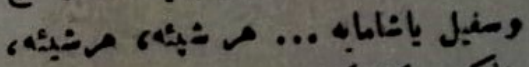

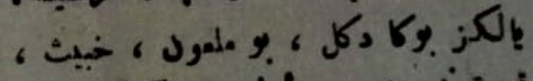

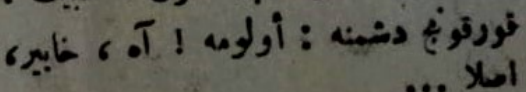

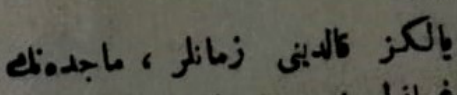

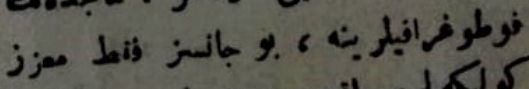

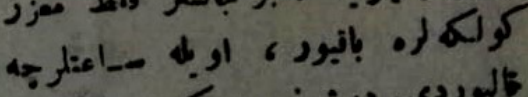

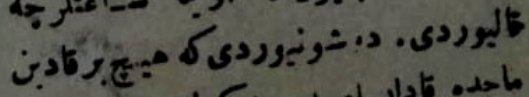

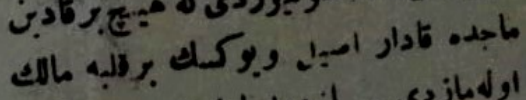

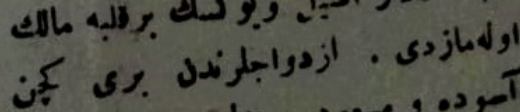

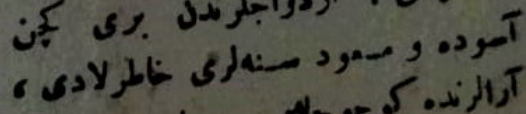

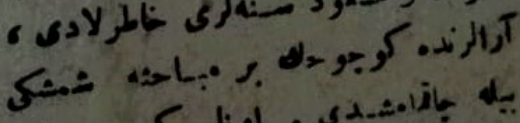

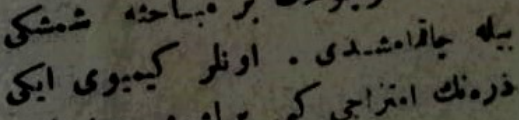

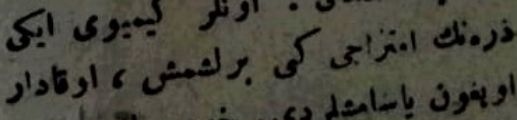

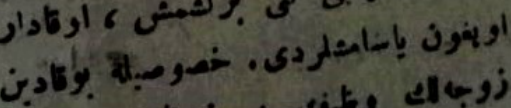

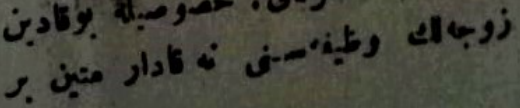




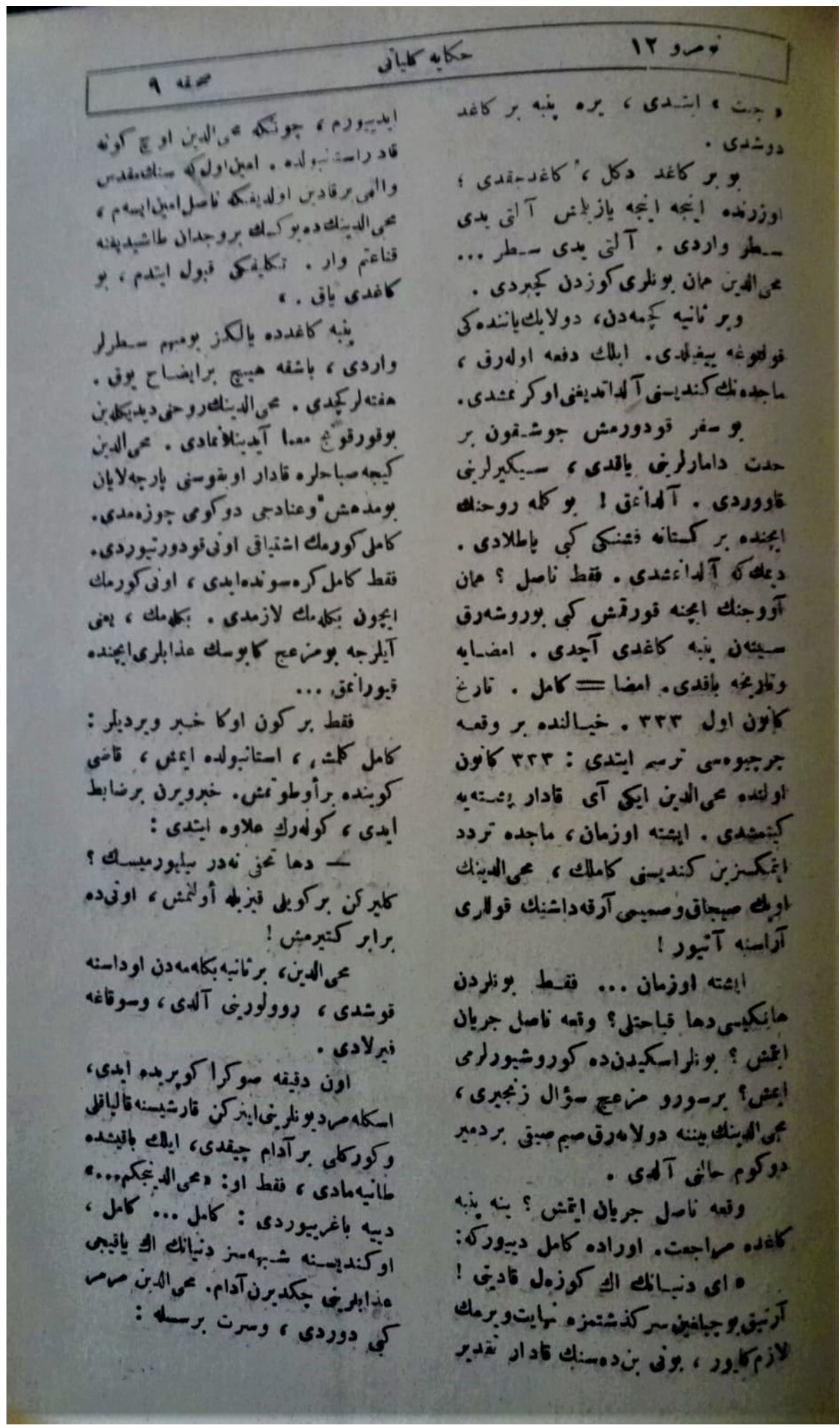




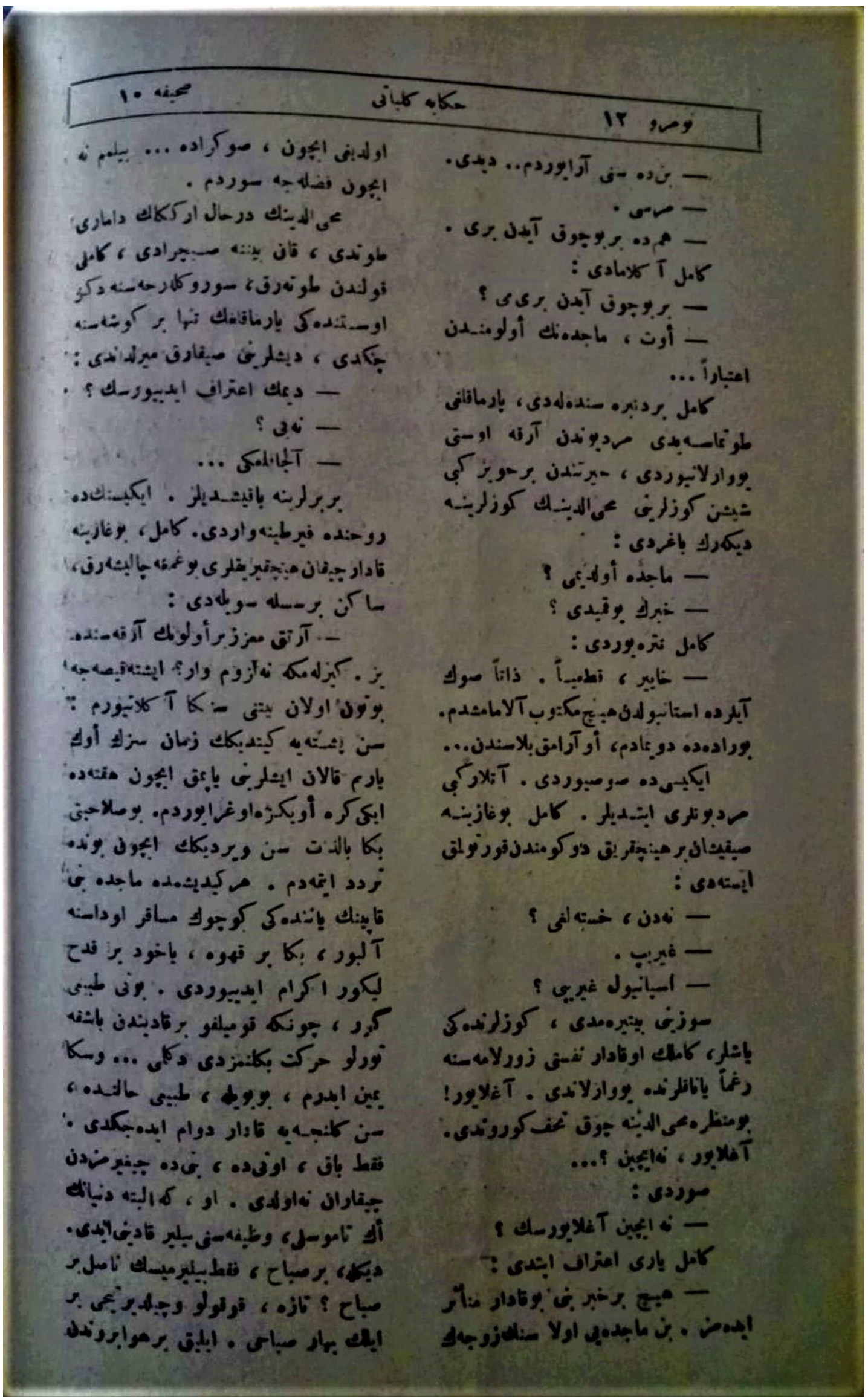




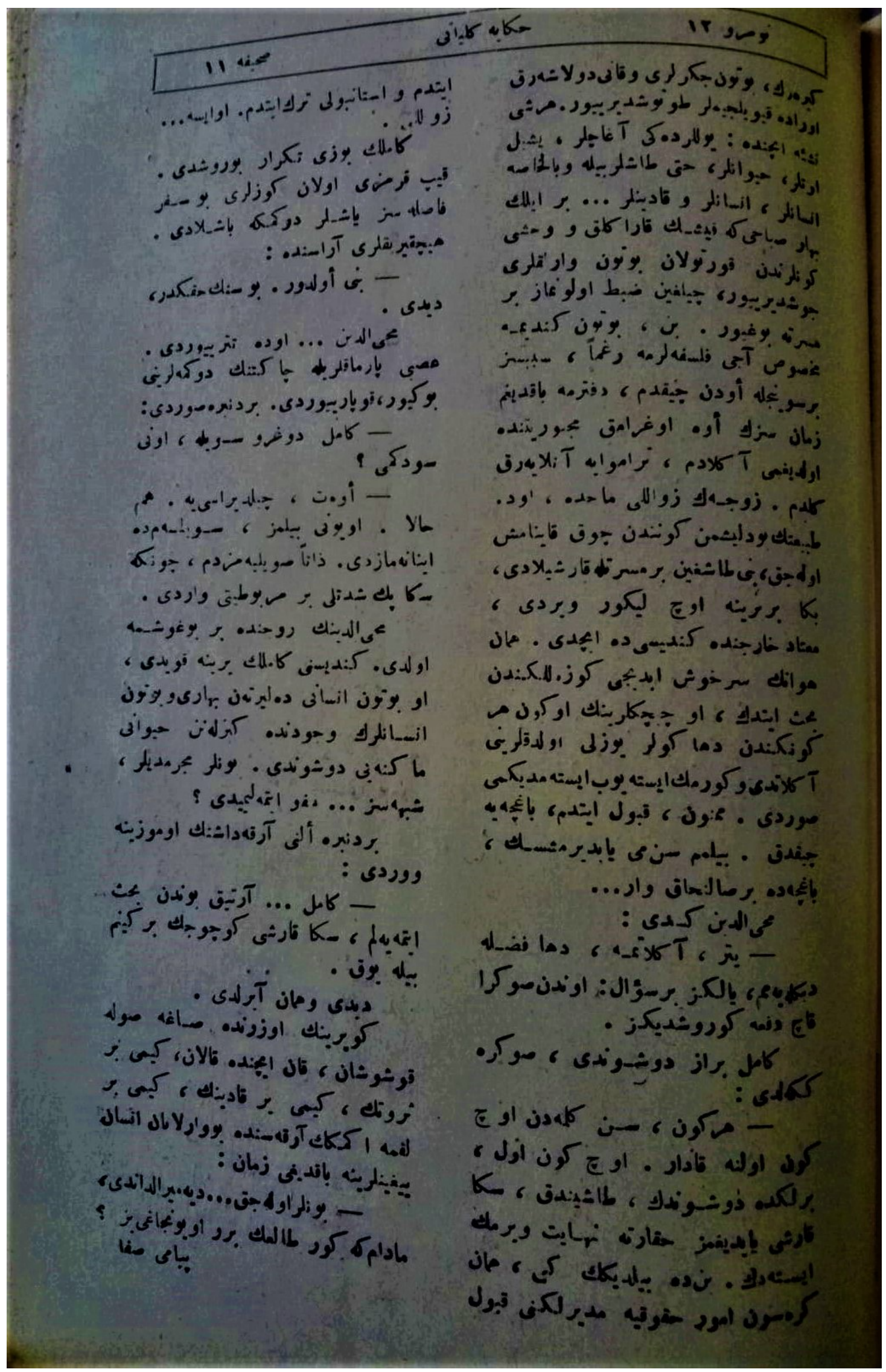

